\title{
GENERAL SCIENCE AND GEOGRAPHY IN THE HIGH SCHOOL.
}

\author{
By John Calvin Hanna, \\ Supervisor of High Schools for Illinois.
}

The writer is like the rest of mankind-he has had some flaws to pick in the scheme of public education; and, furthermore, he is like half of the rest of mankind in that he has had a proposed substitute for some things as they are.

Twenty years ago he became convinced that science study as it was in the high schools of that day needed a thorough overhauling in the direction of adaptation to the needs and the capacity of those just promoted from the elementary schools.

This was the period when the more progressive high schools were quite generally escaping from the "fourteen weeks" system of science instruction. This was the good old plan according to which the youth read more or less interesting statements of more or less important facts and rules grouped in textbooks under the titles-"Physiology," "Chemistry," "Astronomy," "Physics," and then with the characteristic docility of childhood repeated these statements under the pumping process the next day. Some partly useful and fairly reliable information (the doctors will allow us to say "knowledge" in this connection), was accomplished in this way, and a few were led to go on-in the colleges and universities-and to do what was then beginning to be called research work, meaning laboratory work, under the inspired leadership of original and enthusiastic teachers of science.

Some of those who went on, back there in the eighties, returned, after graduation, to the high schools as science teachers, and, rebelling against the memory methods which had been in vogue, instituted laboratories and themselves performed in the awed presence of the youngsters-who meanwhile, with finger in book to mark the place, sat with bated breath-the various flashings and balancings and buildings and explosions that made some of the truths in the book seem a little more real.

This sort of thing, to be sure, had occasionally been done even earlier by some enthusiastic teacher, who "rigged up" apparatus for the purpose, but such an instructor had been considered a wonder, and oftentimes a crank. The ordinary instructor in that antediluvian period had conducted a lesson in any science just as he had done in history, for example. This method involved, on the teacher's part, the making of gentle inquiries as to what was 
"said about" sulphuric acid or the feudal system, as the case might be, and, on the pupil's part, a repetition, with the rising inflection of certain statements on the subject, found on the printed page of "the book." Some people are cruel enough to assert that a considerable part of the science work done in many schools in the present day bears a family resemblance to this oldtime and feeble substitute for real teaching; they even go so far as to say that this sort of thing is not confined to science but is found in English and history classes and the like.

Soon the performing of experiments by the teacher failed to satisfy and a demand came from the universities that a candidate offering, for example, physics as an entrance unit should have actually himself performed certain experiments in the laboratory. Gradually and less completely, this sort of requirement was extended to the other sciences offered for entrance.

The kind of work that was thus set for pupils of fifteen by the young and devoted science teacher, fresh from university laboratory, very naturally was oftentimes altogether beyond their capacity and, in fact, was quite largely a reproduction of the sort of thing that the young scientist had himself just gone through in his postgraduate labors for a master's degree. This ill adaptation of material and methods to the pupil was especially manifest in the biological sciences. In botany, for example, after the "listof-definitions plus fifty-flowers-analyzed" period of education in this field, comes the "compound-microscope plus histology" period when the very young scientist, thrilling inwardly at the proximity of the instructor, who looked over his shoulder and pointed out the adjustments, peeped squintingly through the complicated arrangement of lenses and screws, and obediently said that he saw clearly "in the upper left portion of the field" just what the instructor told him plainly that he should see. Admirably unanimous, but oftentimes admirably inane and largely untruthful!

Such a way of dealing with these matters could not endure. Here and there rebellion arose against this system of science instruction. The writer was one of these rebels and his rebellion was also against the system of confining for a year the attention of the beginner in science study to the narrow limits of one or another of the fields into which scientific phenomena are, for many purposes, very properly grouped. That a beginner, led by the hand of his instructor over the great divide into the marvelous new world of "science," should be compelled, immediately, from the beginning, and persistently for a year to 
confine his attention to "physiography" (which by this time had come to be an equivalent for "an intensified study of the processes and results of erosion") or to "botany" (which similarly had come to be an equivalent for "an intensified study of cell structure and arrangement"), or to "physiology" (which more or less completely had come to be an equivalent for "an intensified study of anatomical phenomena" or possibly of "bacteria and their work" or the like) - such an introduction is wholly inadequate, unfair and dulls the edge of interest.

Surely the youth on the borderland of the new world, standing on the pinnacle of his fresh enthusiasm, has the right to a look over the field, a general survey before he takes up chain and transit for a detailed survey, has a right to a "bird's-eye view" before he begins confining his attention to a "toad's-eye view" in some particular section of the garden of nature.

This feeling led to an early and persistent effort to develop a "Science I" course, to be given to first-year pupils, that should be free from these objections and that positively should fill these following conditions:

1. A course that should introduce the pupil to the observing of natural phenomena and the recognizing of natural laws in a manner adapted to the stage of his maturity, and likely to hold and maintain his interest and stimulate his growth.

2. A course that should serve the purpose of training him, not only to observe with accuracy, but to think to just conclusions from the data thus gathered.

3. A course that should furnish him, in this process, with information which he is likely to find useful in his daily life and which he may thus have stored in his memory, or which he may thus be trained, as he needs it, to go and get, with pleasure and ease and success, by further study or by consulting references.

4. A course that should prepare the way for any further systematic science study that may attract him or be needful.

5. A course that should conform to the Illinois state law which requires that all pupils below the second year of the high school and above the third year of school work shall study physiology and hygiene (including the nature of alcoholic drinks and other narcotics) for not less than four lessons a week for ten or more weeks of each year.

The experiment was wrought out in Oak Park, Ill, and occupied the loyal, devoted, enthusiastic, intelligent efforts of a series of teachers, extending over a term of twelve years, and 
culminating in a "General Science" course (if it be safe to use that term in these controversial days!), or, if safer, an "Elementary Science" course. This course was in successful operation for years before any of the textbooks in "General Science" now on the market were issued.

The reason for referring to it here lies in the belief of the writer, from his observation of conditions in the high schools of the country, that we should come to a plan, in accordance with which all high school students should have a minimum of two science units, with the option of as many more, one or two or even three more units, as the resources of the school can offer and the inclination and need of the pupil demand.

This belief includes also the following points:

1. That the first of these two required science units should be a preliminary view of the field of "science"- the broad field of science seen thus to be one great body of knowledge, to be attacked in one way and to be utilized in the actual affairs of life, to which in all its various fields, it is vitally related.

Such a preliminary view should, in the writer's opinion, include the first-hand study of selected phenomena to assist in making clear certain scientific principles, as these are manifested in several of the above-mentioned fields of science studyphysics, chemistry and biological sciences-all so arranged and presented as to show the interrelation of these groups of knowledge and the relation of all of them to the real affairs of life.

The preface to a late high school text in physics begins thus: "Physics is the summary of a part of human experience. Its development has resulted from the fact that its pursuit has successfully met human needs. Hence, it is believed that the presentation of the subject in the secondary school should be the expansion of the everyday life of the 'pupil into the broader experience and observation of those whose lives have been devoted to the study. Human activity and progress, therefore, should be the teacher's guiding principle, and the bearing of each phenomenon and law on the interests of mankind should be clearly disclosed and emphasized."

Such a statement might very well be put forth as the controlling theory of all science study and should apply, with particular force, to the initial unit of work-first-year science.

A year spent thus-if the course be wisely framed, and if the teachers, in breadth of training, in sympathy of feeling and in skilfulness of teaching, are adapted to it-provides, better than 
any other plan yet offered, an introduction to the new world of science.

It serves as a good working introduction to the way of thinking and doing which science study is mainly aimed to induce, namely, the habits-first, of accurately observing and intelligently recording phenomena; second, of following to logical conclusion by means of clear thinking these principles thus established; third, obeying in the conduct of life the rules of life thus established.

The test of this plan has been made and the results are convincing to everybody that has examined it carefully.

"General Science" in some form as the introductory unit has come to stay. The war over, the "project plan" will settle itself. A thoughtful examination of the statement made above will perhaps show whether this working out of a "Science I" course is an example of the "project plan" of framing a course, or whether it avoids that as a plan of organization.

2. One more question remains: What shall the second required unit be? It may very well be answered in a general way, that the selection of it should be as free as is possible within the limitation-first of the resources of the school as to what courses can be and should be offered; second, of the pupil's interest as awakened in the first year's "preliminary view"; third, of the demands made in the way of preparation for more advanced study or for the profession or occupation to be followed.

It should, moreover, in the writer's opinion, be, if possible, a year's work in one field and in its methods should offer a contrast to the first year's work in one particular, viz.: that it should be as thorough and extensive a study for a year in one field-chemistry, physics, botany, zoollogy, agriculture-as the proper limitations of the high school demand.

If the student can also spend a third year in the high school in science work, let that third year be another year's work in some one field, either the same as or another field than the one occupying his attention in the second year of his science study.

But for years to come, the tendency is likely to be in the direction of confining the science study, for a large number of pupils, to two years.

- One of these then, it seems to the writer, should be the "General Science" or "Elementary Science" referred to and the other unit might be physics for a youth planning to take an engineering course, or chemistry for one planning a medical course, or one 
of the biological units for one planning an agricultural course at the university, and, in general, should be determined, if possible, by the needs of the pupil in his coming years. This question as to the second unit is fairly easy to answer for the groups of students given as illustrations, but the big question remains in many communities: What should such second unit be for that large number of boys (and some girls) who are "going into business," and for that equally large group who "don't know what they're going to do"-but who are going to be intelligent, active and responsible citizens of the community in which they are to live?

The answer to this question is "Geography," the richest and fullest and widest of the sciences, the science that takes up the big problem of Earth and Man and so brings together, appropriately enough, the two streams of thought and work that have carried the young mind along for years.

Geography relates itself to every field of inquiry, to every field of thought, to every field of activity.

It involves a recognition of physical and chemical laws; it has its basis on astronomy and geology; it involves the problems of meteorology and agriculture; it has necessary relations, in both directions, as cause and as effect, to history; the problems of civics, economics, sociology, commerce-all are, in an important sense, problems of geography. Race problems, labor problems, taxation problems, military problems, transportation problems, health and sanitation problems, art problems, religious problemsall have their roots in the science of Earth and Man.

There is much of what the pupil of seventeen had in his work five years earlier which seems to have faded from his memory. Perhaps, a fairer way of putting it is that he has acquired a new point of view since he studied these fundamental subjects that are so vitally related to the life into which he is to be plunged in another year. Because of the acquiring of that new point of view, that youthful point of view, which never will be replaced by the childish point of view, it is worth while-nay, it is necessary-in a well-considered scheme of education, that the youth at this period of his life, before he attacks the specializing work that is to prepare him for his life's work (or at about the same time, if the system of specializing be allowed, as some are suggesting, to begin at least partially at the sixteenth year), at that most important time of his development, I say, it is worth while that he have an opportunity for a review-I know no bet- 
ter word, though it may be misunderstood-of those matters which claimed so large a part of his attention in the elementary school, reading, grammar, arithmetic, American history, geography. Those can all be presented at this latter period in such a way as to command and hold the attention of the rapidly maturing youth of those last two years in the high school program.

One of these, American history, already has such a position, and by general consent in these later days is one of the four regular studies that a twelfth grade student should pursue.

The experiment with American history has proved a great success. No unit in the whole program of studies has won for itself greater confidence as being adapted to the state of the youth's development, as sure to rouse his interest, and challenge the best of his powers, and as of "practical" value in fitting him for the responsibilities and privileges so soon to crowd upon him as a citizen.

As for arithmetic, we all know that there is an immense feebleness in this regard among high school graduates; a weakness leading to sweeping conclusions as to the instruction in the grade schools in that subject. No doubt there is truth in the charge that arithmetic instruction needs improving. No doubt, there is shabby teaching of arithmetic in many places; no doubt, there is needed a better balancing of the time devoted to different parts of the field of arithmetic. But the apparent deficiency is, perhaps, largely due to the neglect of a review in the high school period. A half unit course might very well be prepared and required of all fourth-year pupils that would command interest, call for close and intelligent and thorough work, and fit for meeting the problems of his activities that are to follow upon the completion of his high school course. For a very large number of pupils in the smaller high schools, this half unit would be better than the solid geometry which they generally plow through.

The reading - and I mean both the rapid and accurate taking in of the meaning from the printed page and the intelligent, effective reproduction of that meaning in oral expression-the plain reading in high schools is generally very, very bad. This should be made more and more a part of the English curriculum in every good high scloool; it might very well amount to a full half unit thereof.

Here, also, is the place for the scientific study of grammarwhich was beyond the eighth graders; and with a strong and sympathetic teacher the courșe mạ be made delighțut as well as helpful. 
Something has been attempted in various places with such reviews, reading, arithmetic, grammar, and without, in all cases, degenerating into a cheap and hurried preparation to pass an examination for a certificate to teach.

In the matter of geography, all these reasons apply with especial force. The field is so broad and the material so abundant; the interests involved are so manifold and the interest that may, be aroused is so high, so keen, so enduring and so varied; the practical uses of this study are so plain and so convincing, that the proposition to place geography as a full unit-the second required science unit for a very large number of high school pupils-ought to receive the general and hearty support of school people everywhere.

\section{STORIES.}

"The difference between Fahrenheit and Centigrade thermometers are that on Fahrenheit zero begins at $32^{\circ}$ and on Centigrade it begins at zero or $1^{\circ}$,

"Conduction of heat is when a iron bar is heated at one end it soon becomes heated all over by the heated molecules going along the iron till the end is reached."

\section{TO AID RURAL TEACHERS IN SOUTH.}

To assist teachers in southern rural schools in making their courses of study fit more closely with the farm and home interest of the children, the United States Department of Agriculture will shortly publish a professional paper, Exercises with Plants and Animals for Southern Rural Schools. This bulletin, No. 305 , is in no sense a textbook but is designed merely to be a guide for the teacher. It provides work in studying and observing plants and animals for each of the first five grades. The subjects to be studied by the pupils under the direction of the teacher are arranged by months in such a way that the subject matter may be studied at the time of the year when it is most interesting to the children.

Some of the work suggested is to be done in the classroom but much of it is arranged for field trips by the class. In formulating the exercises, the author had in mind increasing the interest of the children in their regular lessons as well as in the activities in their homes, and training them in outdoor observation by having them study ordinary seeds, plants, insects and animals carefully, under the teacher's guidance. In this way the children are led to discover for themselves much of interest and value in $\mathrm{Na}$ fure that escapes the castal observer. 